\title{
Short Communication: Milk Fat Response to Low Doses of trans-10, cis-12 Conjugated Linoleic Acid (CLA) ${ }^{1,2}$
}

\author{
D. G. Peterson, L. H. Baumgard, ${ }^{3}$ and D. E. Bauman \\ Department of Animal Science \\ Cornell University \\ Ithaca, NY 14853
}

\section{ABSTRACT}

Trans-10, cis-12 conjugated linoleic acid (CLA) is a potent inhibitor of milk fat synthesis. We examined the effect of low doses of trans-10, cis-12 CLA using Holstein cows in a $4 \times 4$ Latin square design. Milk yield and milk protein were unaffected, but abomasal infusion of $1.25,2.5$, and $5.0 \mathrm{~g} / \mathrm{d}$ of trans-10, cis-12 CLA reduced milk fat yield by 7,16 , and $29 \%$, respectively. When combined with previous data, the reduction in milk fat yield was curvilinear, relating to both quantity infused and milk fat content of trans-10, cis-12 CLA $\left(R^{2}=0.99\right.$ and 0.96 , respectively). Further, changes in milk fatty acid composition indicated the mechanism involved inhibition of de novo fatty acid synthesis and the utilization of circulating fatty acids.

(Key words: conjugated linoleic acid, lipogenesis, milk fat depression)

Abbreviation key: CLA = conjugated linoleic acid.

\section{INTRODUCTION}

Conjugated linoleic acids (CLA) are fatty acids found in food products derived from ruminants. Many positional and geometric isomers exist, and CLA studies with animal models have demonstrated a diverse range of beneficial health effects (Pariza et al., 2001). One effect is on nutrient partitioning or more specifically, reduced milk fat synthesis in lactating animals (Bauman et al., 2001) and body fat accretion in growing animals (Jahreis et al., 2000). The decrease in milk fat is caused by trans-10, cis-12 CLA (Baumgard et al.,

\footnotetext{
Received December 6, 2001.

Accepted February 19, 2002.

Corresponding author: D. E. Bauman; e-mail: deb6@cornell.edu.

${ }^{1}$ Supported in part by National Dairy Council (Rosemount, IL), Northeast Dairy Foods Research Center and Cornell Agricultural Experiment Station.

${ }^{2}$ The authors gratefully acknowledge the support and assistance of A. Sæbo, S. Bean, D. Ceurter, B. Corl, D. Dwyer, W. English, M. Madron, and A. Ziegler.

${ }^{3}$ Present address: 228 Shantz, Department of Animal Sciences, University of Arizona.
}

2000), and this isomer has also been implicated in dietinduced milk fat depression (Bauman and Griinari, 2001). Baumgard et al. (2001) recently investigated abomasally infused trans-10, cis-12 CLA and observed a 25 to $50 \%$ reduction in milk fat yield over the dose range of 3.5 to $14.0 \mathrm{~g} / \mathrm{d}$. The present study was conducted to extend this response relationship to lower doses.

Procedures involving animals were approved by the Cornell University Institutional Animal Care and Use Committee. Lactating Holstein dairy cows $(\mathrm{n}=4 ; 3$ primiparous, 1 multiparous) fitted with rumen fistulas were randomly assigned to a $4 \times 4$ Latin square experiment. Cows were housed in tie stalls in an environmentally controlled room with artificial ventilation and 24$\mathrm{h}$ lighting. Cows were fed a TMR consisting mainly of legume and mixed hay and cracked corn that was formulated to meet or exceed predicted nutrient requirements (NRC, 1989), and chemical composition was similar to our previous study (Baumgard et al., 2001). Cows were fed ad libitum and water was available at all times.

Treatments were formulated to deliver $0,1.25,2.50$, and $5.00 \mathrm{~g} / \mathrm{d}$ of trans-10, cis-12 CLA based on a relatively pure CLA supplement (Natural Lipids, Hovdebygda, Norway), which contained $89.3 \%$ trans-10, cis12 CLA. For each experimental period, the CLA supplement was emulsified in skim milk using a microfluidizer (Chouinard et al., 1999), to an initial concentration of $2 \%$ trans-10, cis-12 CLA and then diluted to provide the CLA dose in a volume of $720 \mathrm{ml} / \mathrm{d}$. Infusates passed through the rumen fistula and sulcus omasi into the abomasum via a $0.5-\mathrm{cm}$ (i.d.) polyvinyl chloride tube and were infused in equal portions every $4 \mathrm{~h}(6 \times / \mathrm{d})$ for $5 \mathrm{~d}$ with a 7 -d interval between periods.

Cows were milked at 0600 and $1800 \mathrm{~h}$ and yield recorded. One sample of milk was stored at $4^{\circ} \mathrm{C}$ with a preservative (bronopol tablet; D\&F Control System, San Ramon, CA) until analyzed for fat and protein by infrared analysis (Dairy One Cooperative, Inc., Ithaca, $\mathrm{NY}$ ). A second milk aliquot was stored at $-20^{\circ} \mathrm{C}$ until analyzed for fatty acid composition by gas chromatography as previously described (Baumgard et al., 2001). 
Table 1. Effect of abomasal infusion of trans-10, cis-12 conjugated linoleic acid (CLA) on feed intake and milk composition. ${ }^{1}$

\begin{tabular}{|c|c|c|c|c|c|c|}
\hline \multirow[b]{2}{*}{ Variable } & \multicolumn{4}{|c|}{ trans -10 cis -12 CLA (g/d) } & \multirow[b]{2}{*}{ SEM } & \multirow[b]{2}{*}{$P^{2}$} \\
\hline & 0 & 1.25 & 2.5 & 5.0 & & \\
\hline DMI, kg/d & 24.2 & 23.0 & 23.0 & 21.4 & 1.9 & 0.66 \\
\hline $\begin{array}{l}\text { Milk yield, } \mathrm{kg} / \mathrm{d} \\
\text { Milk fat }\end{array}$ & 31.3 & 31.4 & 31.5 & 28.9 & 2.4 & 0.49 \\
\hline Percent & $3.12^{\mathrm{a}}$ & $2.91^{\mathrm{ab}}$ & $2.60^{\mathrm{bc}}$ & $2.40^{\mathrm{c}}$ & 0.25 & 0.01 \\
\hline Yield, kg/d & $0.97^{\mathrm{a}}$ & $0.90^{\mathrm{a}}$ & $0.81^{\mathrm{ab}}$ & $0.69^{b}$ & 0.08 & 0.04 \\
\hline Milk protein & & & & & & \\
\hline Percent & 2.66 & 2.62 & 2.62 & 2.75 & 0.14 & 0.36 \\
\hline Yield, kg/d & 0.83 & 0.82 & 0.81 & 0.78 & 0.04 & 0.59 \\
\hline
\end{tabular}

${ }^{1}$ Values $(\mathrm{n}=4$ cows) represent $\mathrm{d} 5$ of infusion.

${ }^{2}$ When a treatment effect was significant $(P<0.05)$, differences between treatments were compared by t-test as indicated by superscripts within a row (a, b, c; $P<0.05)$.

Data were analyzed as a $4 \times 4$ Latin square design using the PROC MIXED procedure of SAS (SAS Institute, Cary, NC) according to the model:

$$
\mathrm{Y}_{\mathrm{ijk}}=\mu+\mathrm{D}_{\mathrm{i}}+\mathrm{P}_{\mathrm{j}}+\mathrm{C}_{\mathrm{k}}+\varepsilon_{\mathrm{ijk}}
$$

where $Y_{\mathrm{ijk}}$ is the individual observation, $\mu$ is the overall mean, $D_{i}$ is the effect of dose $(i=1,2,3$, and 4$), P_{j}$ is the effect of period $(\mathrm{j}=1,2,3$, and 4 ; treated as a random effect), $\mathrm{C}_{\mathrm{k}}$ is the effect of cow $(\mathrm{k}=1,2,3$, and 4; treated as a random effect) and $\varepsilon_{\mathrm{ijk}}$ is the residual error term. No significant period effects were observed. Regression analyses were performed using the PROC REG procedure of SAS (SAS Institute).

Performance variables are presented in Table 1. There were no differences among treatments in DMI, milk yield, or milk protein. In contrast, fat percent and yield were reduced in a dose-dependent manner with infusion of trans-10, cis-12 CLA. Effects on milk fatty acid composition provide information on the mechanism by which milk fat synthesis is inhibited. Fatty acids $<\mathrm{C}_{16}$ are synthesized de novo, while fatty acids $>\mathrm{C}_{16}$ arise from uptake of circulating fatty acids and $\mathrm{C}_{16}$ fatty acids originate from both sources. In the present study, the reduction in de novo synthesized and preformed fatty acids contributed similarly (molar basis) to the reduction in milk fat across all doses of trans-10, cis12 CLA (Figure 1). This was also observed by Baumgard et al. (2001) with infusion of $3.5 \mathrm{~g} / \mathrm{d}$ trans-10, cis-12 CLA, but they found more pronounced effects on de novo synthesis at higher doses $(7,10,14 \mathrm{~g} / \mathrm{d})$. In addition, we observed no effects of trans-10, cis-12 CLA on the ratios for fatty acids that represent product/substrate pairs for $\Delta^{9}$-desaturase (data not shown); Baumgard et al. (2001) also observed no effect for their lower dose of trans-10, cis-12 CLA (3.5 g/d), but higher doses ( 7 and $14 \mathrm{~g} / \mathrm{d}$ ) altered the ratios in a manner indicating this

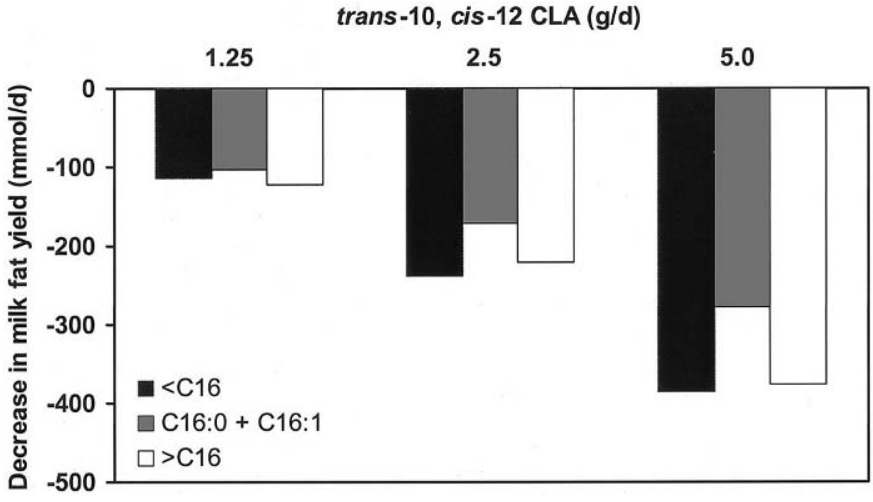

Figure 1. Molar reduction of milk fatty acids from cows receiving trans-10, cis-12 conjugated linoleic acid (CLA) at 1.25, 2.50, and 5.00 $\mathrm{g} / \mathrm{d}$ via abomasal infusion. Values represent means $(\mathrm{n}=4)$ of $\mathrm{d} 5$ of infusion. Fatty acids are categorized according to origin; $<\mathrm{C}_{16}$ represent de novo synthesized fatty acids, $>\mathrm{C}_{16}$ represent preformed fatty acids taken up from circulation, and $\mathrm{C}_{16}$ fatty acids are derived from both sources. To determine the mmol yield of fatty acids, we first calculated yield on a mass basis by multiplying the concentration of each fatty acid in milk fat by the milk fat yield adjusted for triglyceride-glycerol as described by Schauff et al. (1992). Yield on a mass basis was then divided by the molecular weight of each individual fatty acid to calculate yield on a molar basis. SE for $<\mathrm{C}_{16}, \mathrm{C}_{16}$, and $>\mathrm{C}_{16}$ fatty acid groups averaged 10\% across all treatments.

CLA isomer reduced $\Delta^{9}$-desaturase activity. By combining data from different studies, a more complete doseresponse curve for the effects of trans-10, cis-12 CLA on milk fat synthesis can be generated. Figure 2 shows the close curvilinear relationship between trans-10, cis12 CLA dose (g/d) and the corresponding percent reduction in milk fat yield $\left(\mathrm{R}^{2}=0.99 ; P<0.001\right)$ when data

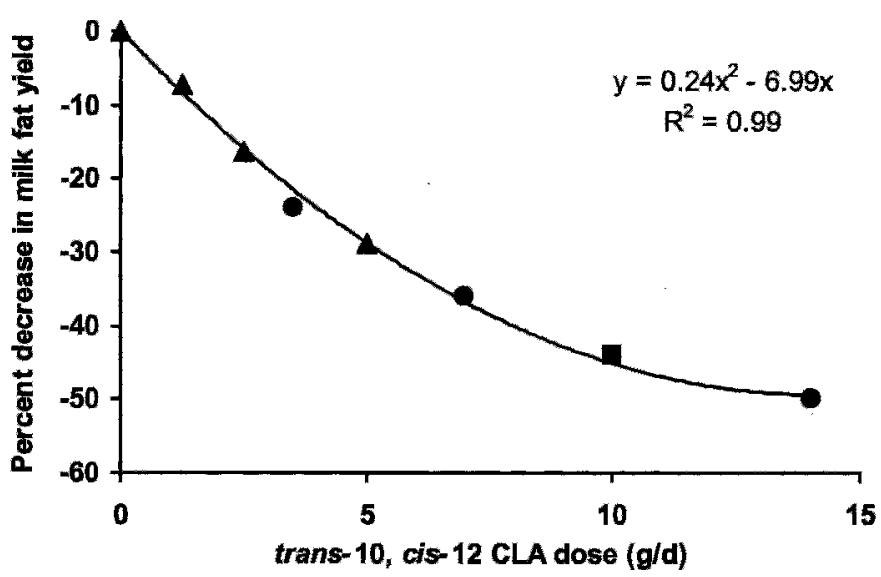

Figure 2. Relationship between the decrease in milk fat yield and dose of trans-10, cis-12 conjugated linoleic acid (CLA) abomasally infused into lactating dairy cows. Triangle symbols represent the values from the present study, circles represent values from Baumgard et al. (2001) and the square represents data from Baumgard et al. $(2000)$. All values represent the mean $(n=4)$ of $d 5$ of infusion. 


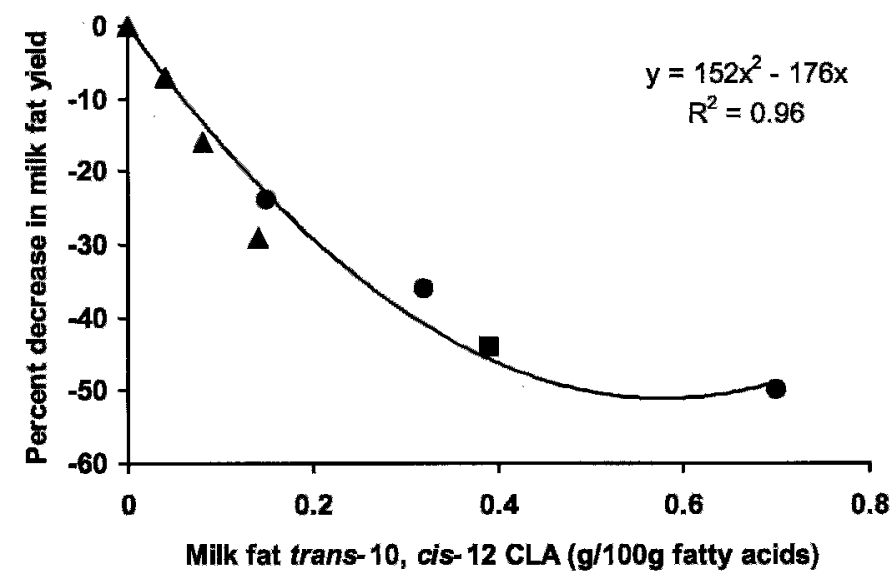

Figure 3. Relationship between the decrease in milk fat yield and milk fat content of trans-10, cis-12 conjugated linoleic acid (CLA) during abomasal infusion into lactating dairy cows. Triangle symbols represent the values from the present study, circles represent values from Baumgard et al. (2001) and the square represents data from Baumgard et al. (2000). All values represent the mean $(n=4)$ of $d 5$ of infusion.

from the present study are combined with two earlier studies (Baumgard et al., 2000; 2001). Trans-10, cis12 CLA is also transferred to milk fat and Figure 3 demonstrates a similar relationship between milk fat content of trans-10, cis-12 CLA, and the corresponding decrease in milk fat yield $\left(\mathrm{R}^{2}=0.96 ; P<0.001\right)$.

Trans-10, cis-12 CLA is a very potent inhibitor of milk fat synthesis in dairy cows. The present study extends our earlier investigations and demonstrates that dose of trans-10, cis-12 CLA and milk fat content of trans-10, cis-12 CLA are curvilinearly related to reduced milk fat yield. Further, consideration of the changes in milk fatty acid composition indicate that the mechanism involves an inhibition of both de novo fatty acid synthesis and uptake and utilization of circulating fatty acids. This is consistent with our previous data indicating trans-10, cis-12 CLA results in coordinated reductions in mammary mRNA abundance for genes involved in uptake and transport of circulating fatty acids, de novo fatty acid synthesis, fatty acid desaturation and formation of triglycerides (Baumgard et al., 2002).

\section{REFERENCES}

Bauman, D. E., and J. M. Griinari. 2001. Regulation and nutritional manipulation of milk fat: Low-fat milk syndrome. Livest. Prod. Sci. 70:15-29.

Bauman, D. E., B. A. Corl, L. H. Baumgard, and J. M. Griinari. 2001. Conjugated linoleic acid (CLA) and the dairy cow. Pages 221-250 in Recent Advances in Animal Nutrition-2001. P. C. Garnsworthy and J. Wiseman, eds. Nottingham University Press, Nottingham, UK.

Baumgard, L. H., B. A. Corl, D. A. Dwyer, A. Saebø, and D. E. Bauman. 2000. Identification of the conjugated linoleic acid isomer that inhibits milk fat synthesis. Am. J. Physiol. 278:R179-R184.

Baumgard, L. H., J. K. Sangster, and D. E. Bauman. 2001. Milk fat synthesis in dairy cows is progressively reduced by increasing supplemental amounts of trans-10, cis-12 conjugated linoleic acid (CLA). J. Nutr. 131:1764-1769.

Baumgard, L. H., E. Matitashvili, B. A. Corl, D. A. Dwyer, and D. E. Bauman. 2002. trans-10, cis-12 CLA decreases lipogenic rates and expression of genes involved in milk lipid synthesis in dairy cows. J. Dairy Sci. (accepted)

Chouinard, P. Y., L. Corneau, D. M. Barbano, L. E. Metzger, and D. E. Bauman. 1999. Conjugated linoleic acids alter milk fatty acid composition and inhibit milk fat secretion in dairy cows. J. Nutr. 129:1579-1584.

Jahreis, G., J. Kraft, F. Tischendorf, F. Schone, and C. von Loeffelholz. 2000. Conjugated linoleic acids: physiological effects in animal and man with special regard to body composition. Eur. J. Lipid Sci. Technol. 102:695-703.

National Research Council. 1989. Nutrient Requirements of Dairy Cattle. 6th rev. ed. Natl. Acad. Sci., Washington, DC.

Pariza, M. W., Y. Park, and M. E. Cook. 2001. The biologically active isomers of conjugated linoleic acid. Prog. Lipid Res. 40:283-298.

Schauff, D. J., J. H. Clark, and J. K. Drackley. 1992. Effects of feeding lactating dairy cows diets containing extruded soybeans and calcium salts of long-chain fatty acids. J. Dairy Sci. 75:3003-3019. 